\title{
The Effect of Chaya Leaf Extract Consumption on Breast Milk Production
}

\author{
$1^{\text {st }}$ V Silawati \\ Faculty of Health Sciences \\ Universitas National Jakarta \\ Jl. Sawo Manila, RT.14/RW.3, Ps. \\ Minggu, Kec. Ps. Minggu, Kota Jakarta \\ Selatan, Daerah Khusus Ibukota Jakarta \\ 12520, Indonesia \\ vivi.sila@civitas.unas.ac.id
}

\author{
$2^{\text {nd }} \mathrm{N}$ Zamzam \\ Midwifery Study Program \\ Faculty of Health Sciences \\ Universitas National Jakarta \\ Jl. Sawo Manila, RT.14/RW.3, Ps. \\ Minggu, Kec. Ps. Minggu, Kota Jakarta \\ Selatan, Daerah Khusus Ibukota Jakarta \\ 12520 , Indonesia a
}

\begin{abstract}
Breast milk contains more than one hundred types of nutrients needed for growth and development of infants. However, many lactating mothers currently do not provide breast milk because of insufficient milk production. This study was conducted to find out the effect of giving Chaya leaf extract on the breast milk production in lactating mothers in Sukarame District, Tasikmalaya in 2019. It was a quasiexperimental research using pretest-posttest with control group design. The research sample consisted of 20 lactating mothers consisting of 10 pregnant women in the control group and 10 pregnant women in the experimental group. Sampling was conducted by purposive sampling technique.This research utilized breast pumps and observation sheets as the research instruments. The statistical test used was a simple Independent t-test. This research obtained Pvalue $0.000<$ 0.005 , which means that there is an effect of consumption of Chaya leaf extract on increasing milk production in lactating mothers in the Sukarame Community Health Center area, Tasikmalaya. Lactating mothers are expected to consume Chaya leaf extract 2-3 times every day.
\end{abstract}

\section{Keywords-Chaya Leaf Extract, Milk, Production}

\section{INTRODUCTION}

Exclusive breastfeeding is carried out to improve the growth, development, health, and survival of infants, which has become one of the global strategies (WHO 2011)[1]. In fact, in West Java, exclusive breastfeeding ranks third lowest. According to Ministry of Health of the Republic of Indonesia (Data and Information Center Ministry of Health Republic of Indonesia/infodatin, 2014)3in 2014, 384,270 of $579,593(33.7 \%)$ infants in West Java were given exclusive breastfeeding. Furthermore, the survey results in the Tasikmalaya district showed that $70.76 \%$ of mothers did not provide exclusive breastfeeding, while data obtained in the Sukarame, Tasikmalaya region indicated that 8 out of 10 mothers (around $70 \%$ ) did not give exclusive breastfeeding. The low number of exclusive breastfeeding was due to the low nutritional status of lactating mothers.Most lactating mothers in Indonesia experienced energy and protein consumption disorders that fell into the deficient category, which was as much as $50 \%$. In addition, energy consumption $<70 \%$ of RDA (Recommended Dietary Allowances) was $33.8 \%$ and the protein consumption was $<80 \%$ RDA (Ministry of Health of the Republic of Indonesia,2016)[2].

As an attempt to increase the rate of secretion and breast milk production, an increase in nutrient intake can be done, one of which is by consuming green vegetables such as Chaya leaves(cnidoscolos aconitifolus) which are already widely used in the United States (kolapo,2016)[3]. Chaya leaves are well-known as traditional medicine in Nigeria to stimulate lactation. It can be consumed easily; by boiling it and consuming the water, while the leaves can be consumed after being cooked/boiled. Considering the importance of Chaya leaf on the breast milk production, this study was conducted to determine the effectiveness of Chaya leaf on the breast milk production in the lactating mothers (iwuji et al,2013)[4].

Breast milk is the most perfect food for babies. It contains all nutrients in the ideal ratio needed by the babies and is useful for their growth and development. The quality and production of breast milk is influenced by mothers' daily food consumption. Thus, during lactation, mothers must consume foods that are healthy, varied and contain balanced nutrition. Inappropriate and unhealthy mother's diet can affect milk production. Consuming foods that contain protein, fruits, and green vegetables that are rich in folic acid can help mothers to produce a lot of quality milk.There are various types of foods that can affect milk production, including katuk leaves, green vegetables, papaya leaves, Chaya leaves and so on.

Musa (2008) affirmed that Chaya leaf extract contains alkaloids and flavonoids which can affect the decrease in plasma LH estradiol and FSH. In 100 grams of Chaya leaves, there are some beneficial minerals for the body, including Protein (5.7gram), energy (258cal), fat 
(0.7gram), calcium (199mg), phosphorus (217mg), iron (11.4mg), vit A (1085IU), vit C (165mg) and carbohydrates (30gram)[4][5].

The presence of these phytochemicals influences changes in circulating hormone levels. Accordingly, the observed increase in prolactin can be attributed to the effect of Chaya leaf extract which acts as a dopamine antagonist. Dopamine functions as a major inhibiting factor for prolactin secretion. High prolactin levels tend to suppress the ovulation cycle by inhibiting secretion while simultaneously stimulating the follicle and Gonadotropic Release Hormone (GnRH) needed for ovulation. Therefore, the increased levels of prolactin in this study justify the use of folkloric extract which functions to stimulate lactation [6][7].

\section{RESEARCH METHOD}

This research was a quasi-experimental, using a pretest and post-test design. Data analysis was performed with an independent $\mathrm{T}$ test. The population was lactating mothers with infants aged 3-28 days (neonates). There were 20 respondents as the samples. Sampling was conducted by purposive sampling technique. The intervention group consumed Chaya leaf and its boiled water 2 times a day for seven days. From this study, the amount of milk production in lactating mothers before and after consuming Chaya leaves wasdiscovered. It also provided information about the effect of Chaya leaves in increasing milk production in lactating mothers.

\section{RESULTS AND DISCUSSION}

\section{A. Results}

TABLE I. THE AVERAGE VALUE OF BREAST MILK PRODUCTION BEFORE AND AFTER CONSUMPTION OF CHAYA LEAVES IN THE INTERVENTION GROUP

\begin{tabular}{|l|c|c|c|c|c|}
\hline & Mean & Median & Modus & Min-max & SD \\
\hline Pre-Experiments & 31 & 30 & 40 & $20-40$ & 7.746 \\
\hline Post-Experiments & 81 & 80 & 80 & $60-100$ & 15.239 \\
\hline
\end{tabular}

The results of analysis in Table I show an increase in the average value of breast milk production after the lactating mothers are given Chaya leaves with a difference value before and after consumption by $50 \mathrm{cc}$.

TABLE II. THE AVERAGE VALUE OF BREAST MILK PRODUCTION BEFORE AND AFTER CONSUMPTION OF CHAYA LEAVES IN THE CONTROL GROUP

\begin{tabular}{|l|c|c|c|c|c|}
\hline & Mean & Median & Modus & Min-max & SD \\
\hline Pretest & 36.5 & 40 & 35 & $20-45$ & 8.515 \\
\hline Posttest & 49.5 & 50 & 55 & $40-60$ & 6.852 \\
\hline
\end{tabular}

The results of the analysis in Table II show that there is a very small increase in the milk production in the group that is not given Chaya leaves, which is only as much as 1.3 cc.

TABLE III. THE DIFFERENCE VALUE IN MILK PRODUCTION BETWEEN THE INTERVENTION AND CONTROL GROUPS

\begin{tabular}{|l|c|c|c|c|}
\hline $\begin{array}{l}\text { Breast Milk } \\
\text { Production }\end{array}$ & Mean & $\begin{array}{c}\text { Standard } \\
\text { Deviation }\end{array}$ & SE mean & P value \\
\cline { 1 - 4 } Intervention & 81.00 & 15.239 & 4.819 & 0.000 \\
\hline Control & 49.50 & 6.852 & 3.000 & \\
\hline
\end{tabular}

The results of the analysis in Table III show that there are differences in the breast milk production in lactating mothers who get Chaya leaves and those who do not with a $\mathrm{P}$ value $<0.005$.

B. Discussions

Based on the results of the study, it was found that there was an effect of Chaya leaf on increasing milk production in lactating mothers. It is in line with a research conducted by Musa (2008) that Chaya leaf can increase milk production sinceit contains alkaloids and flavonoids[6]. The abundance of these two substances in Chaya leaves can increase the prolactin hormone. Prolactin is one of the hormones that affect milk production that the high levels of prolactin automatically increase milk production.

The quality and production of breast milk is influenced by mothers' daily food consumption. During lactation, mothers need to consume foods that are healthy, varied and contain balanced nutrition. Inappropriate and unhealthy mother's diet can affect milk production. Lactating mothers are expected to consume foods that contain protein, fruits, and green vegetables that are rich in folic acid to produce high quality milk [1][7].

Breast milk contains several compositions such as fat, carbohydrates, vitamins, minerals, protein, salt, iron and folic acid. The same content is owned by Chaya leaves so that it can support the production of good quality breast milk. Chaya leaves contain protein, energy, fat, calcium, vitamin $\mathrm{A}$, vitamin $\mathrm{C}$, iron and carbohydrates. The vitamin $\mathrm{C}$ can help to reduce the symptoms of thrush that is frequently experienced by lactating mothers [5][7][8].

\section{CONCLUSION AND SUGGESTION}

One of the efforts to solve problems in improving the quality of maternal health can be done by utilizing local wisdom and natural resources in the community as well as possible, as has been done in Tasikmalaya. The utilization of abundant Chaya leaves in the region could help the 
lactating mothers in getting high nutritional intake as well as doubling the amount of the milk production.

\section{ACKNOWLEDGMENT}

The researcher would like to express the deepest appreciation to the head of the Community Health Center and lactating mothers in Sukarame, Tasikmalaya. Sincere thanks also go to the dean of the Faculty of Health Sciences UNAS, as well as the Midwifery Study Program of the Institute for Research and Community Service (Indonesian: Lembaga Penelitian dan Pengabdian kepada Masyarakat/LPPM) UNAS for the supports so that this research could be carried out well.

\section{REFERENCES}

[1] Kementerian kesehatan RI, "ASI Ekslusif," Kementerian Kesehatan $R I, 2017$.

[2] I. J. Barat, "Cakupan ASI Eklusif di Jawa Barat,” 2014.

[3] K. O. Adeleke, "Effect of Cnidoscolous aconitifolius (miller) i.m. Johnston leaf extract on (miller) i.m. Johnston leaf extract on sperm characteristics and reproductive hormones of male rats," Int. J. Phytomedicine, vol. 8, pp. 228-237, 2016.

[4] D. N. B. Iwuji, Samuel Chidi1*, Nwafor Arthur2, Azeez Taofik Oladimeji1, Nwosu, Emmanuel Chibuike3, Nwaokoro Joakin Chidozie4Egwurugwu, Jude5, "Nutritional and Electrolyte Values of Cnidoscolus aconitifolius(Chaya) leaves consumed in NigerDelta, Nigeria.," Am. J. Pharmtech Res., vol. 3, no. 6, pp. 1-8, 2013.

[5] V. Kuete, Toxicological Survey of African Medicinal Plants., 1st ed. Elsevier, 2014

[6] et. a. Musa Toyin Yakubu1, "Effect of Cnidoscolous aconitifolius (Miller) I.M. Johnston leaf extract on reproductive hormones of female rats.," Iran. J. Reprod. Med., vol. 6, no. 151-154, 2008.

[7] A. M. Jefrey ross, "The Ethnobotany of Chaya (Cnidoscolus Aconitifolius ssp. Aconitifolius Breckon): A Nutritious Maya Vegetable," ReseacrhGAte, vol. 56, no. 4, pp. 350-365, 2002.

[8] L. A. Sarmiento Franco, "Evaluation of Chaya (Cnidoscolus Aconitifolius) Leaf Meal as an Ingredient in Poultry Diets," Edinburgh Res. Arch., 2001. 